\title{
Flexible citizenship for a global society
}

\section{Working Paper}

Author(s):

Frey, Bruno S.

Publication date:

2001

Permanent link:

https://doi.org/10.3929/ethz-a-004374221

Rights / license:

In Copyright - Non-Commercial Use Permitted

Originally published in:

Working paper / Institute for Empirical Research in Economics 94 


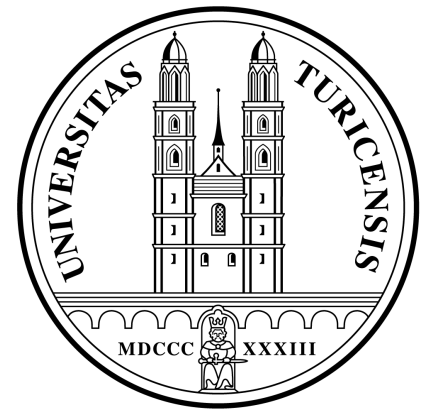

Institute for Empirical Research in Economics

University of Zurich

Working Paper Series

ISSN 1424-0459

forthcoming in:

Journal 'Politics, Philosophy and Economics'

Working Paper No. 94

Flexible Citizenship for a Global Society

Bruno S. Frey

November 2001 


\title{
FLEXIBLE CITIZENSHIP \\ FOR A GLOBAL SOCIETY
}

\author{
by \\ Bruno S. Frey ${ }^{*}$ \\ (University of Zurich)
}

\begin{abstract}
States are ill equipped to meet the challenges of a globalized world. The concept of citizenship with its rights and obligations, including the allegiance owed, is too narrowly defined to exist only between individuals and a state. Today, people identify with, and pay allegiance to, many organizations beyond the state. This paper suggests that citizenship could be extended further and be possible between individuals and quasi-governmental organizations, as well as nongovernmental organizations, such as churches, clubs, interest groups, functional organizations and profit firms. Due to the larger set of types of citizenship individuals could choose from, their preferences would be better fulfilled and, due to the competition for citizens induced among organizations, the efficiency of public activity would be raised.
\end{abstract}

JEL Classification: H1, H4, H7

Keywords: Citizenship, Public Goods, Political Competition

\footnotetext{
* Bruno S. Frey is Professor at the Institute of Empirical Economic Research, University of Zürich, Bluemlisalpstrasse 10, CH-8006 Zurich, Switzerland. Telephone: +41 (01) 6343731. Email: bsfrey@iew.unizh.ch

Earlier versions of this paper were presented at the $2^{\text {nd }}$ Seminar in New Political Economy in Messina, at the International Seminar for New Institutional Economics ISNIE at Tübingen, at the Research Seminar in Economics at the University "La Sapienza" in Rome, at the London School of Economics and at the Conference on "Economic Transition" in Otocic, Slovenia.

I am grateful for helpful comments from Matthias Benz, Peter Bernholz, Trainn Eggertsson, Reiner Eichenberger, Giuseppe Eusepi, Lars Feld, Giancarlo Gandolfo, Gerard Hertig, Reto Jegen, Barbara Krug, Margaret Levi, Stephan Meier, Ram Mudambi, Dennis Mueller, Mario Nuti, Margit Osterloh, Elinor Ostrom, Fabio Padovano, Robert Putnam, Rudolf Richter, Susan Rose-Ackerman, Friedrich Schneider, Alois Stutzer and Stefan Voigt.
} 


\section{INADEQUATE NATION STATES AND NEW CONCEPTS}

We live in the age of the market. Whenever an economic or social problem arises, the knee-jerk reaction is to ask for more market via privatization and deregulation. The government is on the defensive. A standard demand is to run the government as efficiently as private firms. Moreover, the globalization of economic activities undermines many areas in which governments were traditionally active. "A race to the bottom", i.e. continuously falling tax rates and tax revenues due to the tax competition between governments, is often seen as a real danger ${ }^{1}$.

At the same time, governments are in many ways as important as they were throughout the $20^{\text {th }}$ century. A large and rising share of GNP is politically allocated, mainly through the government's redistribution (see e.g. Tanzi and Schuknecht 2000). It has been found that privatization needs governmental re-regulation, globalization depends on rules enforced by governments, and the development of transition economies urgently requires a well-functioning government.

Government, and public activity in general, is still of overriding importance, but the existing institutionalized relationship between individuals and government is ill equipped to cope with the problems of a global world. In particular, to be forced to have the exclusive citizenship of one particular nation only, is inadequate for internationally highly mobile persons such as is the case with many managers, artists, academics, sportsmen and sportswomen. Moreover, multiple identities going above and beyond nationality have become the rule. But the present system

\footnotetext{
1 See e.g. Tanzi 1996, 2000. A theoretical survey of the theory of tax competition is given in Wilson 1999. Quantitative evidence on globalization is extensively collected in Schulze and Ursprung 1999. More general aspects of globalization are e.g. Rodrik 1997, Giddens 1999, or the collection of articles in O'Meara, Mehlinger and Krain 2000.
} 
of citizenship in the nation state also violates the preferences of the "average" person, who often identifies more with a lower level of government (e.g. their particular region) or a higher level of government (e.g. Europe as a whole) rather than with the national level. Even more fundamentally, people often identify more with other organizations such as NGOs or even with particular firms rather than with the nation of which they happen to be citizens.

Societies must find new ways to master the problems that lie ahead in living in an increasingly globalized world. New forms have to be found for the governance of the public sphere. The existing concepts of citizenship were devised in the $19^{\text {th }}$ century in the wake of the French Revolution. The concept remained unchanged in the $20^{\text {th }}$ century: citizens are the subjects of one nation.

This paper advances proposals for a new concept of citizenship designed to be more suited to the public sphere in a global economy and society. The new concept - it will be called COM, which stands for "Citizenship: Organizational and Marginal" - will at first sight appear rather unorthodox, if not revolutionary, compared to today's citizenship. It will certainly meet with strong opposition from politicians in power (who fear losing their monopoly power over what they often still see as their "subjects"), as well as traditional marketeers (who cannot see why governance of the public sphere should be improved, as everything can be accomplished by the market). But the new concept of citizenship contains several features which already exist in one form or another in reality. The proposal is based on the New Institutional Economics and Modern Political Economy or Public Choice (see e.g. Eggertsson 1990, Mueller 1989, 1997). The proposal goes beyond positive analysis; it is clearly normative.

The proposal is diametrically opposed to what has become fashionable today, namely to suggest extending the market to more and more areas. My proposal seeks 
to transfer a relationship typical for the governmental realm - namely citizenship involving identification and commitment or intrinsic motivation - to a more general social setting ${ }^{2}$.

Section II reviews the traditional concept of citizenship. The following section III develops the idea of a generalized citizenship applicable well beyond the realm of the nation state. The proposed citizenship is "Organizational", in the sense that individuals may become citizens not only of states but also of other organizations, such as non-governmental institutions, non-profit organizations and even profitoriented firms. The proposed citizenship is moreover "Marginal" as it can be held temporarily, may be multiple, and even partial, i.e. restricted to some functions only. Section IV discusses the working of COM in terms of voluntary contracts between individuals and organizations, and the interaction extending to include many dimensions. The advantages of COM, compared to the existing form of citizenship, are outlined in section V. In particular, the more adequate alignment of primary identification and citizenship, and the induced increase in efficiency due to strengthening competition, are pointed out. The claimed shortcomings of the new concept of citizenship are the subject of section VI, among other things that it unduly raises complexity, is unfeasible in principle, or will be blocked by political resistance. Concluding remarks are offered in section VII.

2 Instead of "empirialistic economics" (see Stigler 1984, Lazear 2000), i.e. introducing economic concepts into other disciplines, a concept from another discipline is imported into economics. This reverse movement is consistent with Hirshleifer's (1985) claim that empirialist economics runs into diminishing returns (see also Frey 2001). 


\section{TRADITIONAL CITIZENSHIP}

The concept of citizenship goes back to the city states of ancient Greece ${ }^{3}$. Its modern meaning has been defined as follows by the Encyclopedia Britannica:

"Citizenship is a relationship between an individual and a state in which an individual owes allegiance to that state and is in turn entitled to its protection."

Three aspects of this definition have to be noted:

(a) The actors involved are the citizens and the state. Citizenship is a unique and monopolistic relationship between the individuals and a particular nation as has been succinctly summarized by Gordon (1999: 2): "Today, "citizenship" is defined in terms of a nation, and nationalism is the dominant political sentiment of our time ... the hegemonic dominion of the nation is uncontested".

(b) The citizens have both rights and obligations. The rights refer to:

- the civil sphere, i.e. the citizens are protected against the state by the rule of law (or Rechtsstaat) and protected when they are abroad, and they may take up residence within the borders of their state;

- the political sphere, i.e. the citizens, have the right to vote and to hold public office;

- the social sphere, i.e. the citizens are protected against economic hardship within the welfare state.

\footnotetext{
3 See, for instance, the recent books by Kymlicka and Norman 2000, Batstone and Mendieta
} 1999, Dagger 1997, Galston 1991. 
The obligations consist of military (and increasingly social) service, the payment of taxes and law-abiding behavior. At least the last two obligations apply even when a citizen is outwith the borders of his or her own state. Thus, for example, bribery, or having sex with (consenting) minors, is not tolerated, even if it is customary in the foreign country a citizen happens to be in. The citizens also have to accept democratic decisions on a particular matter, even when they are not in their own best personal interests (see Aristotle, and Rousseau's volonté général).

(c) The relationship between an individual and the state goes well beyond an exchange of taxes for public services. Rather, the citizen "owes allegiance" to the state. The citizens are expected to be public spirited and to exhibit civic virtue. The relationship is thus partly non-functional and resorts to the intrinsic motivation of the citizens ${ }^{4}$ and to the community of people who share loyalty and identity (Eriksen and Weigard 2000). This aspect will be of crucial importance in what follows. It distinguishes between the new type of citizenship proposed here and purely being a customer or member of an organization.

Most individuals are citizens of one nation. Only exceptionally is it possible to be a citizen of more than one nation, but most governments strongly discourage or even forbid it. Some persons feel that they are "citizens of the world", or at least "citizens of Europe", but this is no more than a feeling and is of no legal consequence.

\footnotetext{
${ }^{4}$ These aspects are the subject of a large literature mainly in political science, see e.g. Mansbridge 1994, Fukuyama 1995, Levi 1997 or Putnam 1993, 1995, 2000. For contributions in economics, see e.g. Kelman 1987 or Frey 1997a. For law see Cooter (2000). They are also related to social trust, as discussed e.g. in psychology by Kramer and Tyler 1995, and more generally by Cook (2001).
} 


\section{GENERALIZED CITIZENSHIP}

The existing rigid concept of citizenship can be generalized to include four major areas:

\section{Temporary Citizenship}

An individual is able to choose for a predetermined period to become a citizen of a particular nation, for instance because he or she is working and living in the respective country for a specific period of time. During that time, his or her main preoccupation is with the new country, but thereafter it is of little interest. Therefore, in that particular case it does not make sense to adopt the new citizenship for good. But such temporary citizenship is not legally possible at the present time.

\section{Multiple Citizenship}

For persons simultaneously working and living in various countries, a good solution might be to divide the citizenship up into various parts. If the time and intensity of being in one country is approximately the same as in the other, the split might be fifty-fifty. But if the person mainly lives or works in one country, and is only occasionally in the other, an 80 percent citizenship in the first, and a 20 percent citizenship in the second, might be in order.

The rights going with the citizenship must be adjusted accordingly. In particular, the voting rights should reflect the fact that a person chooses to divide citizenship up over several nations. In the age of computers, there is no problem with allowing for fractional votes. Thus, if citizenship is divided fifty-fifty between two nations, the vote should count 0.5 in each country. If the division is 80 to 20 , the vote 
should count 0.8 in the first, and 0.2 in the second country. This rule of course breaks with the time honored principle of "one man, one vote". But once one has accepted the possibility of multiple citizenship, it corresponds to the most basic notion of fairness that the vote is accordingly weighted and not counted fully in each of the two nations ${ }^{5}$.

\section{Partial Citizenship}

An individual might be a citizen of a country with respect to one particular function, while being a citizen of another country with respect to other functions. In referenda, the voting rights should accordingly only extend to issues referring to the respective function.

\section{Citizenship in Various Types of Organizations}

A person may become a citizen of an organization other than the nation. The following possibilities are conceivable:

\section{(a) Levels of Government}

Citizenship might not only refer to the national level - which is the rule - but also to a lower level, such as the region, province or commune (the latter being the case in Switzerland) or to a higher level, such as the European Union. This does not mean, of course, that one can simply opt out and free ride by refusing to pay taxes while still consuming the public goods offered. But it means that no special allegiance is owed to the governmental level of which one does not

\footnotetext{
${ }^{5}$ Different degrees of citizenship are also discussed in Mueller 1996, where the author also distinguishes between a territorial and a cultural citizenship. Tullock 1997 proposes that people should be allowed to exchange, or trade, citizenship.

Several concepts of weighted voting have been developed in different contexts in the Public Choice literature, see e.g. Mueller 1989, 1997.
} 
wish to be a member. A Catalan, for instance, who refuses to be a citizen of Spain, is still taxed for those public goods supplied by the Spanish central government that he or she consumes. But he cannot be forced into helping finance those expenditures by the Spanish central government devoted to other purposes e.g. to building roads in other parts of Spain.

(b) Governmental Sub-Organizations

Individuals might choose to become a citizen of only part of a government, such as the diplomatic service, the military service or the social security administration. Thus, for example, a person with nationality $\mathrm{X}$ may work for, and become a citizen of, the diplomatic service of country $Y$. The special rights and obligations of citizenship would refer to that area only, and not extend beyond. Thus, the person would have a full vote with respect to the diplomatic service (he or she would be treated exactly as the traditional citizens of country Y) while still being an alien with respect to other issues. Historically, many foreigners were effectively, though not legally, "citizens" of governmental suborganizations of another nation, often very successfully. One example is Fürst Metternich, the foreign minister of the Austrian Empire in the time of the Congress of Vienna, who was a German. Or another example is the military leader Prince Eugen of Savoy, who won many battles for Austria even though he was Italian.

(c) Quasi-Governmental Organizations

There are many organizations close to the public sector where individuals might become citizens. Universities provide such an example. Indeed, the institution of "Universitätsbürger" (university citizen) is not uncommon in the German-speaking academic system. It obviously means much more than just 
being an "employee" of a university. Rather, a university citizen is prepared to commit him- or herself to the academy without considering the short-term purely personal benefits and costs.

(d) Non-Governmental Organizations (NGOs)

Citizenship in the following types of organizations can well be envisaged:

- Churches, for instance the Catholic Church (whose high functionaries have indeed a citizenship of their own provided by the Vatican State) or religious orders;

- Clubs, for instance the Rotary Club, the Boy Scouts or even sport clubs such as Manchester United or FC Barcelona;

- Interest Groups, for instance trade unions and international chambers of commerce; action groups, such as the World Wildlife Fund; charities such as the "Médecins sans Frontières" and the Red Cross.

- Functional Organizations, e.g. ICANN, the "Internet Cooperation for Assigned Names and Numbers", which is a virtual center of the Internet, providing web addresses, and the Root Server establishing connections between the different web sites. ICANN has a virtual citizenry which in 2000 was allowed for the first time to vote for the election of (some of) the reigning body (see, more generally Engel and Keller 2000). This dimension of citizenship relates to the concept of Functional, Overlapping, Competing Jurisdictions $(F O C J)^{6}$.

${ }^{6}$ Frey and Eichenberger 1999; for a critique Vaubel 2000. 
- Profit-Oriented Firms. Citizens of firms have a special relationship to their company, which goes beyond just being a customer or employee. Being a citizen of a firm is not the same as being a shareholder or a stakeholder. Shareholders have a decision weight according to the number of shares, while stakeholders have no formal voting right at all but exert external pressure, mainly through the media and demonstrations In contrast, each citizen of a firm has a vote according to generally accepted democratic principles. Such voting rights are not necessarily incompatible with shareholders' voting rights. Firm citizenship can exist very well along with shareholding ${ }^{7}$.

Management economics has coined the term "corporate citizenship" to indicate an intrinsically motivated relationship of employees with their firm. The concept has been generalized to "organizational citizenship"(see e.g. Organ 1990, Van Dyne, Graham and Dienesch 1994). It includes such behavior as cooperation, supporting superiors and co-workers, enhancing the reputation of the organization, suggesting improvements, as well as abstaining from harming the organization e.g. by antisocial, counterproductive, deviant and maladaptive behavior. There is indeed a special "psychological" contract (see Rousseau 1995) between the employers and employees in the organization, which goes beyond short-term egoistic motives.

Individuals might choose to establish citizenship with a national firm (particularly one in which they work themselves) or with an international firm. An example of the latter would be citizenship with a credit card firm or with an airline. Such

\footnotetext{
7 The two voting principles can co-exist perfectly well. This has been demonstrated by the formal co-determination rights that exist in Germany. In that country, in companies exceeding 2,000 employees, the shareholders and the representatives of the employees hold the same number of seats in the Aufsichtsrat, the main decision-making body. This arrangement works quite well and is largely undisputed today.
} 
corporations are well equipped to support citizens in their international travels. Not only can they guarantee the identity of the person, but also his or her financial status, as certified by travel documents or by computerized means. Moreover, such firms can arrange work residence and work permits for their citizens with the various nations. There was indeed a time when American Express actually performed several of these services for many US citizens abroad, and the same holds for airlines such as Lufthansa and Swissair. Such firms often have more resources at their disposal, and are more efficient and flexible, than the traditional diplomatic service.

\section{THE FUNCTIONING OF THE NEW CITIZENSHIP SYSTEM}

"Citizenship: Organizational and Marginal" (COM) is based on voluntary contracts between the persons aspiring to citizenship of a particular organization and the organization offering the possibility of citizenship. These contracts are necessarily incomplete because it is impossible to state all the contingencies that the future might bring.

An essential feature of citizenship is that an organization can expect a measure of allegiance and loyalty from its members. Citizens are prepared to abstain from exploiting in a calculating way all the short-term advantages available. "Citizenship" means that the members exhibit an intrinsically based motivation to support "their" organization ${ }^{8}$ in a way that goes beyond purely egoistic calculations.

\footnotetext{
${ }^{8}$ As President John F. Kennedy said in his inaugural speech: "Ask not what your country does for you, rather ask what you can do for your country". But Kennedy restricts such behavior, and thus citizenship, to the national level. Needless to say, people's willingness to act in such an altruistic way towards the state has often been exploited by governments. The First World War provides a drastic example, and applied to all nations involved in this conflict.
} 
To envisage such non-selfish behavior would seem to be naive and is indeed at odds with the basic credo of the rational choice approach (see e.g. Becker 1976, Lazear 2000, Frey 1999) as well as with the traditionally conceived "Law and Economics" (e.g. Posner 1986, Hirsch 1976; in contrast to Cooter 1984 and Cooter and Ulen 2000). While these approaches have been most successful, they have overlooked aspects not captured by egoistic benefit-cost calculations.

Over the last few years, theoretical and empirical research has made considerable progress. We now have strong and cumulative empirical evidence that under many conditions individuals are prepared to contribute substantially to what they consider the common good even if it is not in their individual egoistic interests to do so. Free riding in the presence of public goods (as analyzed by Olson 1965) remains a serious problem, especially when people feel that others do not contribute their fair share, or when the situation is purely anonymous and the possible gain is all too large. But extensive field studies ${ }^{9}$ confirm that incentives to free ride need not dictate behavior, especially when the persons know, and communicate with, each other. There is similar evidence from a large number of carefully controlled laboratory experiments ${ }^{10}$. No less than 40 to 60 percent of subjects in a one-shot public good situation contribute to the provision of a pure public good. The level of cooperation remains between 30 and 50 percent of what would be socially optimal, even after many repetitions (e.g. Dawes, McTavish and Shaklee 1977, Ledyard 1995, Bohnet and Frey 1997, 1999). But such cooperation is not naive; in many situations people contribute to a common good only if people in the reference

\footnotetext{
${ }^{9}$ (See, in particular Ostrom 1990, 2000a,b, Ostrom, Gardner and Walker 1994.

${ }^{10}$ (See, for instance, Bowles 1998, Fehr and Schmidt 1999, Fehr and Gächter 2000, Bowles and Gintis 2001.
} 
group do likewise ${ }^{11}$. This type of conditional cooperation is supported and enhanced by the institution of generalized citizenship. The voluntary citizenship contract establishes formal rules applying to every citizen, which serves to prevent unfair behavior.

These insights link up with the rapidly growing research pointing out the importance of social capital for individuals' behavior in the political and general social setting (Putnam 1993, 2000, Coleman 1990). There is now a wide consensus among social scientists that intrinsic motivation, loyalty, or social capital, is an indispensable resource for a well functioning society ${ }^{12}$. When it is insufficiently developed, or scarcely exists, society threatens to break down or at least functions at a low level of efficiency. Thus care must be taken to protect it. It has indeed been shown in experiments (Deci and Ryan 1985, Deci, Koestner and Ryan 1999), as well as in field research (Frey 1997b, Frey and Jegen 2001), that external interventions, which are taken to be controlling by the persons affected, may crowd out intrinsic motivation.

Citizenship thus does not only rely on a measure of civic virtue but also serves to strengthen such intrinsic motivation. The citizenship contract is based on a mutual belief in good intentions. The leaders of the organization expect their citizens to exhibit allegiance and loyalty, and conversely the citizens expect the organization to put its trust in them. As a result, civic virtue tends to be supported or crowded in. A voluntary citizenship contract constitutes a formal acknowledgment that a special relationship exists between the individual and the organization beyond a purely selfish benefit-cost calculation. More deeply underlying intrinsic values, as well as

\footnotetext{
${ }^{11}$ For experimental evidence on conditional cooperation and reciprocity see, for instance, Keser and van Winden 2000, Fehr and Gächter 2000. The theoretical background has been explored by e.g. Sugden 1982, Rabin 1993.

12 One may add that this also holds for relationships within firms, see Osterloh and Frey 2000.
} 
emotions ${ }^{13}$, are involved. Citizenship cannot be divorced from such "hot" factors. This element distinguishes citizenship fundamentally from a traditional producercustomer relationship.

The citizenship contract specifies the rules governing the relationship and the mutual obligations. This includes the taxes to be paid by the citizens in return for the public services rendered, as well as the political participation rights of the citizens, e.g. the right to elect the organization's directors and to initiate citizens' initiatives and referenda. The larger the pure public good part of the public activity provided by an organization, the more intensively political participation rights will be sought by the citizens. It is to be expected that the most intensive participation will be sought in the case of governmental organizations, as the very raison d'être of the state lies in the provision of public goods (see e.g. Mueller 1989). But it is equally clear that it is not only governments which supply goods and services with public good characteristics, but many other organizations too - including (of course to a more limited extent) profit-oriented firms ${ }^{14}$.

The contracts are public in the sense that a citizen cannot contract for any individual service, as would be possible on a market. Rather, a citizen could participate in the consumption of the pure or impure public goods supplied by the organization of which he or she is a member. COM thus refers to "club"-goods in the sense of Buchanan (1965), where non-members can be excluded but where the consumption among the citizens has public good characteristics. But Buchanan's analysis only looks at the benefits and costs an additional member creates, while he

\footnotetext{
13 Emotions, or visceral factors, are a topic economists have only most recently become aware of (e.g. Frank 1988, Loewenstein 2000, Akerlof and Kranton 2000).

14 The vanishing borders between "private" and "public" are discussed, e.g. in Weisbrod 2000, in the case of charitable, cultural and health organizations.
} 
neglects what has been stressed above, namely the special relationship between the members and their club based on intrinsic motivations such as trust and loyalty.

The citizenship contract has a public component in that entry and exit are guided by formal rules. These rules serve to prevent unfair discrimination between individuals and lower transaction costs. A person meeting the requirements for being a citizen of an organization must be admitted, and he or she is permitted to exit when the general conditions applying to all the citizens are met. An organization can apply specific conditions for citizenship in a similar way to what nations do nowadays. But it can use innovative ideas to do so. For instance, persons wanting to work in a specific region may be able to offer money for this privilege instead of having to depend on a haphazard bureaucratic or random system. Exit also depends on conditions mostly relating to the past consumption of publicly supplied goods. Thus, a person who received a heavy subsidy, or even an essentially free education, can be asked to pay back the corresponding amount if he or she wants to exit the organization.

\section{ADVANTAGES OF THE NEW CONCEPT OF CITIZENSHIP}

\section{A. Opening Up More Flexible Solutions}

The existing concept of citizenship, with its principle of immutable, monopolistic and lifelong attachment to one nation, in many respects does not fit the requirements of persons acting in a global society. This holds in particular for internationally highly mobile persons, such as managers of global firms (e.g. of IBM or $\mathrm{ABB}$ ), sportsmen and sportswomen (e.g. Formula 1 racing drivers or top tennis players), artists (e.g. opera singers or conductors) or scientists teaching at several universities across the world. The traditional nationality concept is also 
inadequate for some ethnic groups such as the Sinti and Roma, whose nomadic life style is inconsistent with being citizens of one particular nation.

The concept COM opens up several possibilities for making citizenship more flexible:

(a) temporary citizenship according to the period of time spent with a particular organization;

(b) multiple citizenship according to the amoung of time spent with each organization;

(c) partial citizenship according to functions, e.g. with respect to international travel with a global firm (say, American Express) and with respect to state old age pensions with the social security system of some country.

\section{B. Allowing Multiple Identifications}

In the $19^{\text {th }}$ and the first part of the $20^{\text {th }}$ century, the major focus of identification for many people may have been the nation. But even today the idea of one single, deeply ingrained national identity still survives. According to COM, a person it not limited to belonging to only one nation, religion or ethnicity. Rather, today's world is characterized by belonging to many different entities at the same time: a person may well be a Swiss, a catholic, an academic, an adherent of a sports club, as well as being a member of a charitable organization. As so often happens, novelists have grasped the essential point in a convincing way. Amin Maalouf in his book "Les identités meurtrières" (1998) writes:

"I do not possess several identities, I possess only one identity, comprising all the elements which have gone into its formation, creating 
that unique "mixture" which differentiates one person from another." (p.7-8, my translation).

Maalouf was born a Lebanese and has been living in France for 22 years. He writes in French but his mother tongue is Arabic, the holy language of Islam; he nevertheless is a Christian but not a Roman-Catholic.

The change from a national citizenship to one composed of many different components has so far not been acknowledged; the concept of citizenship has remained unchanged throughout the $19^{\text {th }}$ and $20^{\text {th }}$ century. But today many people feel close to several countries and to other types of organizations and not solely to one nation and one nation only. Especially among the younger generations, the sense of an exclusive national identification has appreciably declined.

The concept of COM allows individuals to become citizens of organizations they strongly identify with. They are therefore willing to engage in a relationship in which they not only have rights but also obligations (going beyond the payment of taxes). The following are some examples of non-national citizenship:

(a) A person might identify with a lower level than the national level, in particular a regional level. Pertinent examples are certain people from Catalunya who are strongly attached to their language and culture, but do not wish to be nationals of Spain (or of any other nation for that matter). Some individuals might even identify more with their city or commune than with any other governmental level. Accordingly, it makes sense that they are able to fulfil their preferences by becoming citizens of the corresponding local jurisdiction.

(b) A person's identification might be with a higher level of government. There are people who feel that they are no longer citizens of their nation, but citizens of Europe or of NATO. The concept of COM would allow them to opt for this 
kind of citizenship without having to wait for a fully-fledged "State of Europe"(which will perhaps never happen). In contrast, those persons who are less taken with the European unification process could keep their national citizenship.

(c) Many academics today have much closer relationships with their peers at universities located in other, often far away, countries than with other persons in the country where they live and work. They might become citizens of their own university or of university systems extending across various nations.

(d) Many individuals closely identify with their religious denomination. The example of the Catholic Church has already been mentioned. Such persons should be able to become citizens of their church; they are prepared to accept the corresponding mutual rights and obligations. Citizenship could also be envisaged for a part of a church. To stay with the example of the Catholic Church: a Cistercian monk, for example, has devoted his life to Christ, represented on earth by his order. He is truly a citizen of the Cistercian order. The traditional concept of citizenship forces him instead to be a citizen of a particular nation, with which he has no practical or spiritual connection.

(e) Sport addicts often identify with "their" club. Pertinent examples are European football clubs. Such persons should have the possibility of becoming citizens of, say, Manchester United or FC Barcelona. As in many previous examples, there is no relationship to a nation. In the case of FC Barcelona, there was the situation recently that eight of the eleven top players, as well as the coach, had Dutch nationality. With citizenship, the persons, as well as the clubs, assume rights and obligations. The establishment of citizenship would help to tackle the problem of hooliganism. Today, the clubs are held responsible for any damage done by their fans, even outside of the stadium. It is unclear on what basis the 
clubs are held responsible, because they do not have any formal relationship with the supporters other than selling them an entry ticket to a game. With COM, the relationship between fans and clubs would be intensified and formalized, and the clubs could therefore require their citizens to behave in an appropriate way.

(f) Many persons feel closely related to an action group in which they (often voluntarily) work and to which they contribute money. The individuals active in "Médecins sans Frontières" and in the Red Cross make a distinct effort to disassociate themselves from any particular nation in order to be able to efficiently carry out their noble tasks. For such persons, it would be advantageous to become a citizen of these organizations (possibly for a restricted time period) rather than to have to hide their nationality. The Red Cross has actually split over this issue. The League of Red Cross Associations is comprised of nationally oriented sections, which tend to concentrate on national tasks, and principally care for the wounded and POWs of their own country, which is scarcely compatible with Dunant's fundamental idea of the Red Cross. The International Committee of the Red Cross endeavors to correct this shortcoming by spanning all countries. In an effort to overcome conflicting national interests, it has been ruled that the members of the ruling body, the Committee, are solely composed of citizens of a neutral country, Switzerland, because of it being a neutral country. This construction is well suited to harness the strife between nations, but one nation is exclusively favored. While this solution is probably better than having all nations lobbying and using bullying tactics to get seats on the Committee, COM offers a better alternative. The members of the Committee, who must be supposed to be fully engaged in their task, should adopt the citizenship of the Red Cross. 
(g) In internationally oriented firms, the nationality of the top managers, as well as of many of the employees, has become irrelevant. An example is the chemical company Roche, whose eight member executive board is composed of managers of six nationalities, five of whom (also) have Swiss nationality. As nationality is largely irrelevant, and these managers in the course of their careers have worked in many different countries, citizenship with the firm would present an attractive alternative to the present national citizenship.

\section{Fostering the Willingness to Contribute to Public Goods}

The loyalty, commitment and engagement supported and enhanced by establishing citizenship connections strengthen individuals' willingness to voluntarily contribute to the financing of publicly provided goods and services. It would, of course, be naive to assume that taxes are paid voluntarily. On the other hand, research by economists ${ }^{15}$ has established beyond doubt that tax paying behavior cannot be explained by the government exerting force. Indeed, "A purely economic analysis of the evasion gamble implies that most individuals would evade if they are "rational", because it is unlikely that cheaters will be caught and penalized" (Alm, McClelland and Schulze 1992: 22). But most people, more than 95 percent, actually pay the taxes due.

Neither of the extreme positions is realistic: people do not pay taxes voluntarily, nor do they do so only because they are forced to. What matters is that the civic virtue increased by citizenship tends to significantly raise people's willingness to financially contribute to public activities. Being categorized as a citizen produces a feeling of identity, which in turn acts as a constraint on behavior. Due to this identification, citizens are less prone to exploiting other people by acting as free-

15 See the surveys by Andreoni, Erard and Feinstein 1998 and Slemrod 1992, as well as the studies by Graetz and Wilde 1985, Skinner and Slemrod 1985, Frey 1997c. 
riders. Identity does not only act as a constraint on choice but induces people to refrain from a conscious calculus of choice (Monroe 2001, Monroe, Hankin and VanVechten 2000, Tajfel 1970). This facilitates the supply of the respective goods and services in a global environment, where the use of force by organizations and governments is severely limited as no world government with a monopoly of power exists.

\section{Better Preference Fulfillment}

COM allows individuals a broader choice. Citizenship would no longer be restricted to nations, and would not be imposed at birth. Rather, individuals would have the possibility of selecting whatever form of citizenship they find most advantageous in their own lives. This choice is not one-sided. The organizations offering citizenship would impose membership conditions. In particular, they would stipulate the obligations, such as a specific degree of commitment.

Individuals would be better able to find a citizenship arrangement suitable for them. They can enter a public contract where their likes and dislikes are taken into account. The case of a strong supporter of European integration, who can personally choose to become a citizen of Europe, or the members of a certain ethnicity, who want to associate themselves with their region and opt out of their nation, have already been mentioned. And persons who dislike the nation as an institution could become citizens of non-national organizations, such as NGOs or global firms.

\section{E. Higher Efficiency of Public Activities}

Following COM, the state loses the monopoly over a considerable set of activities traditionally considered to be the realm of the government. The nation is exposed to competition from lower and higher levels of government, foreign nations, as well 
as NGOs and profit-oriented firms. As a result of this larger opportunity set, exit would be facilitated, and all the organizations supplying citizenship would be induced to offer attractive conditions. This contrasts strongly with today's national monopoly, where an individual has a high price to pay when deciding to exit. Efficiency is also increased by the fact that citizenship could flexibly be adjusted to meet the present and still unknown future demand for publicly provided goods and services.

\section{CLAIMED DISADVANTAGES}

As is always the case with an unconventional idea, many arguments may be raised against the new concept of citizenship. The following four seem to be particularly important.

\section{Citizenship is not needed.}

It could be argued that the concept of citizenship is unnecessary, because an individual can get all the services on the market by private contract.

This argument does not hold, as many of the goods provided by governmental and non-governmental organizations to some extent have public good characteristics, for which - due to free riding incentives - private provision does not function sufficiently well. Moreover, citizenship entails more than just buying a good or a service. Citizens must be prepared to commit themselves to the organization. They cannot behave in a purely selfish way and be solely extrinsically motivated. Rather, they must be prepared to abstain from short-term opportunistic behavior; they must to some extent be intrinsically motivated. Only then will public activity of sufficient quantity and quality be forthcoming. The experience of the transition 
economies has made perfectly clear that behavior based on civic virtue is required, and that markets cannot substitute for everything.

\section{The new concept of citizenship has high transaction costs.}

It might be argued that the transaction costs for the individuals would increase to too high levels when they could choose between many different suppliers of citizenship.

It is certainly true that COM enlarges the possibility set, and in this sense complicates the world. But the extended possibilities of choice simply reflect a more complex global world. While COM introduces some new evaluation and decision costs, it should not be overlooked that the present monopolistic supply of citizenship also imposes costs: the choice set of individuals is strongly limited by restricting citizenship to one single nation. With increasing globalization and enlarged opportunities, these costs tend to rise sharply.

\section{The new system of citizenship is infeasible.}

It may be argued that making citizenship more flexible "does not work in reality".

However, in many important respects, aspects of COM are already in existence. Some examples are:

(a) Multiple national citizenship exists to a limited extent. But, more importantly, the citizens of federal states are in actual fact, though not always legally, already members of several (governmental) organizations.

(b) In several countries, foreigners have voting rights at the local level. Thus, the citizens of an EU-nation have the right to vote in the local elections of another 
EU-country in which they reside (Article 19 (8b) ECT). In this sense, multiple and partial citizenship already exists ${ }^{16}$.

(c) Diplomats have an international status which could be called "citizenship in the diplomatic service", providing them with a number of goods with public good characteristics. A case is immunity, which could not be bought on the market. Similarly, the World Bank already issues passports to its employees, with which they are able to travel worldwide ${ }^{17}$.

(d) The top persons in the Catholic Church, the Pope, the Cardinals and other clerics active in the central administration, have a citizenship of their own, vested in the minute Vatican State.

(e) People are "citizens" of condominiums in many urban settings. In Seoul, for example, a very large proportion of the residents of the city live in relatively large-scale condominiums. Each such resident belongs to a floor organization, a building organization and to an overall condominium organization. This federal system may involve as many as 10,000-20,000 people, who must pay a monthly fee in order to stay in the condominium. Some of these condominiums hire as many as 200-500 staff members, who provide a variety of social services such as day-care and recreation. Each "citizen" is required to pay what might be considered taxes to provide a variety of public goods for the condominium. It is almost impossible to tell the difference between some of these condominiums and what is called local government in other settings ${ }^{18}$.

\footnotetext{
${ }^{16}$ Already in ancient Rome there was "full" and "partial" citizenship. The latter had the same legal status as the former in all private matters, but they could not vote in the assemblies or stand for office ( see e.g. Gordon 1999: 93).

17 Personal communication by Dennis Mueller, 25 September 2000.

18 Personal communication by Elinor Ostrom, 2 October 2000.
} 
The COM-system would not require a sudden institutional change. It could be introduced in small steps. The first individuals who would probably take advantage of the new type of citizenship are the internationally highly mobile managers, sports people, artists and academics. Persons satisfied with their present national citizenship would not have to take any action.

\section{The new system of citizenship will be politically opposed.}

Without any doubt, the politicians presently in charge are strongly motivated to reject flexible citizenship because it would rob or undermine their monopoly power. The same holds for public officials who benefit from the fact that, in many respects, the citizens do not have any alternatives. For example, what can a national citizen do if the public bureaucracy refuses to issue a passport? In many nations, recourse to courts is slow, costly in terms of time and money, or simply ineffective.

COM is not acceptable by persons who, as a matter of principle, want to restrict the term "citizen" to the traditional meaning. It will certainly be difficult for many to consider modifying such a time-honored concept. The same holds for "marketeers", who want to improve the world by expanding the realm of the price system by pushing back the state.

\section{CONCLUSIONS}

Citizenship entails a special relationship, consisting both of rights and obligations going far beyond short-term and egoistic exchanges between individuals and the state. The concept of citizenship has traditionally been reserved exclusively for the nation state. But states have proved to be unable to meet the challenges of a global world. The existing state monopoly of citizenship is too narrow and inefficient and 
conflicts with the tasks to be solved by public activities. Citizenship, with its rights and obligations, can be generalized and made more flexible. Temporary, multiple and partial citizenship may be extended to quasi-governmental and nongovernmental organizations, including churches, clubs, interest groups, functional organizations and profit-oriented firms. Indeed, the notion of academic, corporate, organizational, industrial and functional citizenship can be observed in one form or another in reality. To extend citizenship to organizations beyond the nation increases the choice set of individuals; raises the willingness to finance publicly provided goods and services in the global economy; leads to better preference fulfillment, establishes more intensive competition between the many organizations able to provide public activities, and therewith raises efficiency. 


\section{References}

Akerlof, George A. and Rachel E. Kranton (2000). Economics and Identity. Quarterly Journal of Economics 115 (3): 715-753.

Alm, James, Gary McClelland and William D. Schulze (1992). Why Do People Pay Taxes. Journal of Public Economics 48 (1): 21-38.

Andreoni, James, Brian Erard and Jonathan Feinstein (1998). Tax Compliance. Journal of Economic Literature 36 (2): 818-860.

Batstone, David and Eduardo Mendieta (eds) (1999). The Good Citizen. London: Routledge.

Becker, Gary S. (1976). The Economic Approach to Human Behavior. Chicago: Chicago University Press.

Bohnet, Iris and Bruno S. Frey (1997). Rent Leaving. Journal of Institutional and Theoretical Economics (JITE) 153 (4): 711-721.

Bohnet, Iris and Bruno S. Frey (1999). Social Distance and Other-Regarding Behavior in Dictator Games: Comment. American Economic Review 89 (1): 335-339.

Bowles, Samuel (1998). Endogenous Preferences: The Cultural Consequences of Markets and Other Economic Institutions. Journal of Economic Perspectives 36 (1): 75-111.

Bowles, Samuel and Herbert Gintis (2001). The Evolution of Strong Reciprocity. Working Paper, Dept. of Economics, University of Massachusetts, Amherst.

Buchanan, James M. (1965). An Economic Theory of Clubs. Economica 32 (1): 1-14.

Coleman, James S. (1990). Foundations of Social Theory. Cambridge, MA: Harvard University Press.

Cooter, Robert D. (1984). Prices and Sanctions. Columbia Law Review 84: 1523-1560.

Cooter, Robert D. (2000). Do Good Laws Make Good Citizens? An Economic Analysis of Internalizing Legal Values. Virginia Law Review (forthcoming).

Cooter and Ulen (2000). Law and Economics. Reading, Mass.: Addison, Wesley, Longman.

Dagger, Richard (1997). Civic Virtues: Rights, Citizenship, and Republican Liberalism. Oxford: Oxford University Press. 
Dawes, Robyn M., Jeanne McTavish and Harriet Shaklee (1977). Behavior, Communication, and Assumptions about other People's Behavior in a Commons Dilemma Situation. Journal of Personality and Social Psychology 35 (1): 1-11.

Deci, Edward L. (1971). Effects of Externally Mediated Rewards on Intrinsic Motivation. Journal of Personality and Social Psychology 18 (1): 105-115.

Deci, Edward L. and Richard M. Ryan (1985). Intrinsic Motivation and Self-Determination in Human Behavior. New York: Plenum Press.

Deci, Edward L., Richard Koestner and Richard M. Ryan (1999). A Meta-Analytic Review of Experiments Examining the Effects of Extrinsic Rewards on Intrinsic Motivation. Psychological Bulletin 125 (6): 627-668.

Eggertsson, Thrainn (1990). Economic Behaviour and Institutions: Principles of Neoinstitutional Economics. Cambridge: Cambridge University Press.

Eichenberger, Reiner (1999). Dereguliert, Liberalisiert und Globalisiert die Politik. Ein Politischökonomischer Reformvorschlag. Studia Philosophica 58: 99-121.

Engel, Christoph and Kenneth H. Keller (eds) (2000). Governance of Global Networks in the Light of Differing Local Values. Baden-Baden: Nomos.

Eriksen, Erik Oddvar and Jarle Weigard (2000). The End of Citizenship? New Roles Challenging the Political Order. Arena Working Papers (http:www.sv.uio.no/arena/publications/wp99).

Fehr, Ernst and Simon Gächter (2000), Fairness and Retaliation: The Economics of Reciprocity. Journal of Economic Perspectives 14 (3): 159-181.

Fehr, Ernst and Klaus M. Schmidt (1999). A Theory of Fairness, Competition and Cooperation. Quarterly Journal of Economics 114 (3): 817-868.

Frank, Robert H. (1988). Passions with Reason. The Strategic Role of the Emotions. New York: Norton.

Frey, Bruno S. (1997a). A Constitution for Knaves Crowds Out Civic Virtues. Economic Journal 107 (443): 1043-1053. 
Frey, Bruno S. (1997b). Not Just for the Money. An Economic Theory of Personal Motivation.

Edward Elgar: Cheltenham UK and Brookfield, US. German: Markt und Motivation. Vahlen: München.

Frey, Bruno S. (1997c). Ein neuer Federalismus für Europa: Die Idee der FOCJ. Mohr Siebeck: Tübingen.

Frey, Bruno S. (1999). Economics as a Science of Human Behaviour. 2nd rev. and extended ed., Boston and Dordrecht: Kluwer.

Frey, Bruno S. (2001). Inspiring Economics. Human Motivation in Political Economy. Edward Elgar: Cheltenham UK and Northhampton USA.

Frey, Bruno S. and Reiner Eichenberger (1999). The New Democratic Federalism for Europe:

Functional, Overlapping and Competing Jurisdictions. Edward Elgar: Cheltenham UK and Northhampton USA.

Frey, Bruno S. and Reto Jegen (2001). Motivation Crowding Theory: A Survey of Empirical Evidence. Journal of Economic Surveys (im Druck).

Fukuyama, Francis (1995). Trust: The Social Virtues and the Creation of Property. New York: Free Press.

Galston, William A. (1991). Liberal Purposes: Goods, Virtues, and Diversity in a Liberal State. Cambridge: Cambridge University Press.

Giddens, Anthony (1999). Runaway World: How Globalization is Reshaping Our Lives. London: Profile Books.

Gordon, Scott (1999). Controlling the State. Constitutionalism from Ancient Athens to Today. Cambridge, Mass. and London: Harvard University Press.

Graetz, Michael J. and Louis L. Wilde (1985). The Economics of Tax Compliance: Facts and Fantasy. National Tax Journal 38 (September): 355-363.

Hirsch, Fred (1976). The Social Limits to Growth. Cambridge, Mass.: Harvard University Press. Hirshleifer, Jack (1985). The Expanding Domain of Economics. American Economic Review 75 (6): 53-68. 
Kelman, Steven (1987). Making Public Policy: A Hopeful View of American Government. New York: Basic Books.

Keser, Claudia and Frans van Winden (2000). Conditional Cooperation and Voluntary Contributions to Public Goods. Scandinavian Journal of Economics 102: 23-39.

Kramer, Roderick M. and Tom R. Tyler (1996). Trust in Organizations. Thousand Oaks: Sage.

Kymlicka, Will and Wayne Norman (eds) (2000). Citizenship in Diverse Societies. Oxford: Oxford University Press.

Lazear, Edward (2000). Economic Imperialism. Quarterly Journal of Economics 115: 99-146.

Ledyard, John O. (1995). Public Goods: A Survey of Experimental Research. In: John Kagel and Alvin E. Roth (eds) Handbook of Experimental Economics. Princeton: Princeton University Press: 111-194.

Levi, Margaret (1997). Consent, Dissent and Patriotism. Cambridge: Cambridge University Press.

Loewenstein, George (2000). Emotions in Economic Theory and Economic Behavior. American Economic Review, Papers and Proceedings 90 (May): 426-432.

Maalouf, Amin (1998). Les Identités Meurtrières. Paris: Grasset \& Fasquelle. German: Mörderische Identitäten. Frankfurt: Suhrkamp 2000.

Mansbridge, Jane J. (1994). Public Spirit in Political Systems. In: Henry J. Aaron, Thomas E. Mann and Timothy Taylor (eds) Values and Public Policy. Washington: Brookings: 146-172.

Mueller, Dennis C. (1989). Public Choice II. 2nd ed., Cambridge: Cambridge University Press. Mueller, Dennis C. (1996). Constitutional Democracy. New York: Oxford University Press. Mueller, Dennis C. (1997). Perspectives on Public Choice. Cambridge: Cambridge University Press.

Olson, Mancur (1965). The Logic of Collective Action. Cambridge, Mass.: Harvard University Press.

O’Meara, Patrick, Howard D. Mehlinger and Matthew Krain (eds) (2000). Globalization and the Challenges of the New Century: A Reader. Bloomington: Indiana University Press. 
Organ, Dennis W. (1990). The Motivational Basis of Organizational Citizenship Behavior. Research in Organizational Behavior 12: 43-72.

Osterloh, Margit and Bruno S. Frey (2000). Motivation, Knowledge Transfer and Organizational Forms. Organization Science 11, No. 5 (September-October 2000): 538-50.

Ostrom, Elinor (1990). Governing the Commons: the Evolution of Institutions for Collective Action. Cambridge: Cambridge University Press.

Ostrom, Elinor (2000a). Collective Norms and the Evolution of Social Norms. Journal of Economic Perspectives 14: 137-158.

Ostrom, Elinor (2000b). Crowding Out Citizenship. Scandinavian Political Studies 23 (1): 3-16.

Ostrom, Elinor, Roy Gardner and James Walker (1994). Rules, Games, and Common-Pool Resources. Ann Arbor: University of Michigan Press.

Posner, Richard A. (1986). The Economic Analysis of Law. 3rd ed., Boston: Little \& Brown.

Putnam, Robert D. (1993). Making Democracy Work. Princeton: Princeton University Press.

Putnam, Robert D. (1995). Tuning In, Tuning Out: The Strange Disappearance of Social Capital in America. PS: Political Science and Politics 28 (4): 664-683.

Putnam, Robert D. (2000). Bowling Alone: The Collapse and Revival of American Community. New York: Simon \& Schuster.

Rabin, Matthew (1993). Incorporating Fairness into Game Theory and Economics. American Economic Review 83 (5): 1281-1302.

Rodrik, Dani (1997). Has Globalization Gone Too Far? Institute for International Economics, Washington D.C.

Rousseau, Denise M. (1995). Psychological Contracts in Organizations: Understanding Written and Unwritten Agreements. Thousand Oaks, London and New Delhi: Sage Publications.

Schulze, Günther G. and Heinrich W. Ursprung (1999). Globalization of the Economy and the Nation State. World Economy 22 (3): 295-352.

Skinner, Jonathan and Joel Slemrod (1985). An Economic Perspective on Tax Evasion. National Tax Journal 38 (3): 345-353. 
Slemrod, Joel (ed.) (1992). Why People Pay Taxes. Tax Compliance and Enforcement. Ann Arbor: University of Michigan Press.

Stigler, George J. (1984). Economics - The Imperial Science? Scandinavian Journal of Economics 86 (3): 301-313.

Sugden, Robert (1984). Reciprocity: The Supply of Public Goods through Voluntary Contirbutions. Economic Journal 94 (376): 772-787.

Tanzi, Vito (1996). Globalization, Tax Competition and the Future of Tax Systems. IMF Working Paper 96/14, Washington D.C.

Tanzi, Vito (2000). Globalization, Technological Developments and the Work of Fiscal Termites. IMF Working Paper 00/181, Washington D.C.

Tanzi, Vito and Ludger Schuhknecht (2000). Public Spending in the $20^{\text {th }}$ Century. A Global Perspective. Cambridge: Cambridge University Press.

Tullock, Gordon (1997). Trading Citizenship. Kyklos 50 (2): 251-252.

Van Dyne, Linn, Jill W. Graham and Richard M. Dienesch (1994). Organizational Citizenship Behavior: Construct Redefinition, Measurement and Validation. Journal of Management 34: 765-802.

Vaubel, Roland (2000). Internationaler Politischer Wettbewerb: Eine europäische Wettbewerbsaufsicht für Regierungen und die empirische Evidenz. Jahrbuch für Neue Politische Ökonomie 19: 280-309.

Weisbrod, Burton A. (ed.) (2000). To Profit or Not to Profit: The Dilemma of Commercializing the Non-Profit Sector. Cambridge UK: Cambridge University Press.

Wilson, John D. (1999). Theories of Tax Competition. National Tax Journal 53 (2): 269-304. 


\section{Working Papers of the Institute for Empirical Research in Economics}

No.

1. Rudolf Winter-Ebmer and Josef Zweimüller: Firm Size Wage Differentials in Switzerland: Evidence from Job Changers, February 1999

2. Bruno S. Frey and Marcel Kucher: History as Reflected in Capital Markets: The Case of World War II, February 1999

3. Josef Falkinger, Ernst Fehr, Simon Gächter and Rudolf Winter-Ebmer: A Simple Mechanism for the Efficient Provision of Public Goods - Experimental Evidence, February 1999

4. Ernst Fehr and Klaus M. Schmidt: A Theory of Fairness, Competition and Cooperation, April 1999

5. Markus Knell: Social Comparisons, Inequality, and Growth, April 1999

6. Armin Falk and Urs Fischbacher: A Theory of Reciprocity, July 2000

7. Bruno S. Frey and Lorenz Goette: Does Pay Motivate Volunteers?, May 1999

8. Rudolf Winter-Ebmer and Josef Zweimüller: Intra-firm Wage Dispersion and Firm Performance, May 1999

9. Josef Zweimüller: Schumpeterian Entrepreneurs Meet Engel's Law: The Impact of Inequality on InnovationDriven Growth, May 1999

10. Ernst Fehr and Simon Gächter: Cooperation and Punishment in Public Goods Experiments, June 1999

11. Rudolf Winter-Ebmer and Josef Zweimüller: Do Immigrants Displace Young Native Workers: The Austrian Experience, June 1999

12. Ernst Fehr and Jean-Robert Tyran: Does Money Illusion Matter?, June 1999

13. Stefan Felder and Reto Schleiniger: Environmental Tax Reform: Efficiency and Political Feasibility, July 1999

14. Bruno S. Frey: Art Fakes - What Fakes?, An Economic View, July 1999

15. Bruno S. Frey and Alois Stutzer: Happiness, Economy and Institutions, July 1999

16. Urs Fischbacher, Simon Gächter and Ernst Fehr: Are People Conditionally Cooperative? Evidence from a Public Goods Experiment, July 2000

17. Armin Falk, Ernst Fehr and Urs Fischbacher: On the Nature of Fair Behavior, August 1999

18. Vital Anderhub, Simon Gächter and Manfred Königstein: Efficient Contracting and Fair Play in a Simple Principal-Agent Experiment, September 2000

19. Simon Gächter and Armin Falk: Reputation or Reciprocity? Consequences for the Labour Relation, July 2001

20. Ernst Fehr and Klaus M. Schmidt: Fairness, Incentives, and Contractual Choices, September 1999

21. Urs Fischbacher: $z$-Tree - Experimenter's Manual, September 1999

22. Bruno S. Frey and Alois Stutzer: Maximising Happiness?, October 1999

23. Alois Stutzer: Demokratieindizes für die Kantone der Schweiz, October 1999

24. Bruno S. Frey: Was bewirkt die Volkswirtschaftslehre?, October 1999

25. Bruno S. Frey, Marcel Kucher and Alois Stutzer: Outcome, Process \& Power in Direct Democracy, November 1999

26. Bruno S. Frey and Reto Jegen: Motivation Crowding Theory: A Survey of Empirical Evidence, November 1999

27. Margit Osterloh and Bruno S. Frey: Motivation, Knowledge Transfer, and Organizational Forms, November 1999

28. Bruno S. Frey and Marcel Kucher: Managerial Power and Compensation, December 1999

29. Reto Schleiniger: Ecological Tax Reform with Exemptions for the Export Sector in a two Sector two Factor Model, December 1999

30. Jens-Ulrich Peter and Klaus Reiner Schenk-Hoppé: Business Cycle Phenomena in Overlapping Generations Economies with Stochastic Production, December 1999

31. Josef Zweimüller: Inequality, Redistribution, and Economic Growth, January 2000

32. Marc Oliver Bettzüge and Thorsten Hens: Financial Innovation, Communication and the Theory of the Firm, January 2000

33. Klaus Reiner Schenk-Hoppé: Is there a Golden Rule for the Stochastic Solow Growth Model? January 2000

34. Ernst Fehr and Simon Gächter: Do Incentive Contracts Crowd out Voluntary Cooperation? February 2000

35. Marc Oliver Bettzüge and Thorsten Hens: An Evolutionary Approach to Financial Innovation, July 2000

36. Bruno S. Frey: Does Economics Have an Effect? Towards an Economics of Economics, February 2000

37. Josef Zweimüller and Rudolf Winter-Ebmer: Firm-Specific Training: Consequences for Job-Mobility, March 2000

The Working Papers of the Institute for Empirical Research in Economics can be downloaded in PDF-format from http://www.unizh.ch/iew/wp/ 


\section{Working Papers of the Institute for Empirical Research in Economics}

No.

38. Martin Brown, Armin Falk and Ernst Fehr: Contract Inforcement and the Evolution of Longrun Relations, March 2000

39. Thorsten Hens, Jörg Laitenberger and Andreas Löffler: On Uniqueness of Equilibria in the CAPM, July 2000

40. Ernst Fehr and Simon Gächter: Fairness and Retaliation: The Economics of Reciprocity, March 2000

41. Rafael Lalive, Jan C. van Ours and Josef Zweimüller: The Impact of Active Labor Market Programs and Benefit Entitlement Rules on the Duration of Unemployment, March 2000

42. Reto Schleiniger: Consumption Taxes and International Competitiveness in a Keynesian World, April 2000

43. Ernst Fehr and Peter K. Zych: Intertemporal Choice under Habit Formation, May 2000

44. Ernst Fehr and Lorenz Goette: Robustness and Real Consequences of Nominal Wage Rigidity, May 2000

45. Ernst Fehr and Jean-Robert Tyran: Does Money Illusion Matter? REVISED VERSION, May 2000

46. Klaus Reiner Schenk-Hoppé: Sample-Path Stability of Non-Stationary Dynamic Economic Systems, Juni 2000

47. Bruno S. Frey: A Utopia? Government without Territorial Monopoly, June 2000

48. Bruno S. Frey: The Rise and Fall of Festivals, June 2000

49. Bruno S. Frey and Reto Jegen: Motivation Crowding Theory: A Survey of Empirical Evidence, REVISED VERSION, June 2000

50. Albrecht Ritschl and Ulrich Woitek: Did Monetary Forces Cause the Great Depression? A Bayesian VAR Analysis for the U.S. Economy, July 2000

51. Alois Stutzer and Rafael Lalive: The Role of Social Work Norms in Job Searching and Subjective Well-Being, July 2000

52. Iris Bohnet, Bruno S. Frey and Steffen Huck: More Order with Less Law: On Contract Enforcement, Trust, and Crowding, July 2000

53. Armin Falk and Markus Knell: Choosing the Joneses: On the Endogeneity of Reference Groups, July 2000

54. Klaus Reiner Schenk-Hoppé: Economic Growth and Business Cycles: A Critical Comment on Detrending Time Series, May 2001 - Revised Version

55. Armin Falk, Ernst Fehr and Urs Fischbacher: Appropriating the Commons - A Theoretical Explanation, September 2000

56. Bruno S. Frey and Reiner Eichenberger: A Proposal for a Flexible Europe, August 2000

57. Reiner Eichenberger and Bruno S. Frey: Europe's Eminent Economists: A Quantitative Analysis, September 2000

58. Bruno S. Frey: Why Economists Disregard Economic Methodology, September 2000

59. Armin Falk, Ernst Fehr, Urs Fischbacher: Driving Forces of Informal Sanctions, May 2001

60. Rafael Lalive: Did we Overestimate the Value of Health?, October 2000

61. Matthias Benz, Marcel Kucher and Alois Stutzer: Are Stock Options the Managers' Blessing? Stock Option Compensation and Institutional Controls, April 2001

62. Simon Gächter and Armin Falk: Work motivation, institutions, and performance, October 2000

63. Armin Falk, Ernst Fehr and Urs Fischbacher: Testing Theories of Fairness - Intentions Matter, September 2000

64. Ernst Fehr and Klaus Schmidt: Endogenous Incomplete Contracts, November 2000

65. Klaus Reiner Schenk-Hoppé and Björn Schmalfuss: Random fixed points in a stochastic Solow growth model, November 2000

66. Leonard J. Mirman and Klaus Reiner Schenk-Hoppé: Financial Markets and Stochastic Growth, November 2000

67. Klaus Reiner Schenk-Hoppé: Random Dynamical Systems in Economics, December 2000

68. Albrecht Ritschl: Deficit Spending in the Nazi Recovery, 1933-1938: A Critical Reassessment, December 2000

69. Bruno S. Frey and Stephan Meier: Political Economists are Neither Selfish nor Indoctrinated, December 2000

70. Thorsten Hens and Beat Pilgrim: The Transfer Paradox and Sunspot Equilibria, January 2001

71. Thorsten Hens: An Extension of Mantel (1976) to Incomplete Markets, January 2001

72. Ernst Fehr, Alexander Klein and Klaus M. Schmidt: Fairness, Incentives and Contractual Incompleteness, February 2001

73. Reto Schleiniger: Energy Tax Reform with Excemptions for the Energy-Intensive Export Sector, February 2001

74. Thorsten Hens and Klaus Schenk-Hoppé: Evolution of Portfolio Rules in Incomplete Markets, October 2001

The Working Papers of the Institute for Empirical Research in Economics can be downloaded in PDF-format from http://www.unizh.ch/iew/wp/

Institute for Empirical Research in Economics, Blümlisalpstr. 10, 8006 Zürich, Switzerland

Phone: 004116343705 Fax: 004116344907 E-mail: bibiewzh@iew.unizh.ch 


\section{Working Papers of the Institute for Empirical Research in Economics}

No.

75. Ernst Fehr and Klaus Schmidt: Theories of Fairness and Reciprocity - Evidence and Economic Applications, February 2001

76. Bruno S. Frey and Alois Stutzer: Beyond Bentham - Measuring Procedural Utility, April 2001

77. Reto Schleiniger: Global $\mathrm{CO}_{2}$-Trade and Local Externalities, April 2001

78. Reto Schleiniger and Stefan Felder: Fossile Energiepolitik jenseits von Kyoto, June 2001

79. Armin Falk: Homo Oeconomicus Versus Homo Reciprocans: Ansätze für ein Neues Wirtschaftspolitisches Leitbild?, July 2001

80. Bruno S. Frey and Alois Stutzer: What can Economists learn from Happiness Research?, October 2001

81. Matthias Benz and Alois Stutzer: Was erklärt die steigenden Managerlöhne? Ein Diskussionsbeitrag, June 2001

82. Peter A.G. VanBergeijk and Jan Marc Berk: The Lucas Critique in Practice: An Empirical Investigation of the Impact of European Monetary Integration on the Term Structure, July 2001

83. Igor V. Evstigneey, Thorsten Hens and Klaus Reiner Schenk-Hoppé: Market Selection of Financial Trading Strategies: Global Stability, July 2001

84. Why Social Preferences Matter - The Impact of Non-Selfish Motives on Competition, Cooperation and Incentives

85. Bruno S. Frey: Liliput oder Leviathan? Der Staat in der Globalisierten Wirtschaft, August 2001

86. Urs Fischbacher and Christian Thöni: Inefficient Excess Entry in an Experimental Winner-Take-All Market, August 2001

87. Anke Gerber: Direct versus Intermediated Finance: An Old Question and a New Answer, September 2001

88. Klaus Reiner Schenk-Hoppé: Stochastic Tastes and Money in a Neo-Keynesian Econom, August 2001

89. Igor V. Evstigneev and Klaus Reiner Schenk-Hoppé: From Rags to Riches: On Constant Proportions Investment Strategies, August 2001

90. Ralf Becker, Thorsten Hens and Urs Fischbacher: Soft Landing of a Stock Market Bubbl. An Experimental Study, September 2001

91. Rabah Amir, Igor V. Evstigneev, Thorsten Hens, Klaus Reiner Schenk-Hoppé: Market Selection and Survival of Investment Strategies, October 2001

92. Bruno S. Frey and Matthias Benz: Ökonomie und Psychologie: eine Übersicht, Oktober 2001

93. Reto Schleiniger: Money Illusion and the Double Dividend in the Short Run, October 2001

94. Bruno S. Frey: Flexible Citizenship for a Global Society, November 2001

The Working Papers of the Institute for Empirical Research in Economics can be downloaded in PDF-format from http://www.unizh.ch/iew/wp/

Institute for Empirical Research in Economics, Blümlisalpstr. 10, 8006 Zürich, Switzerland

Phone: 004116343705 Fax: 004116344907 E-mail: bibiewzh@iew.unizh.ch 